\title{
Challenges of Biopolitics Caused by the COVID-19 Pandemic
}

\author{
Deyev A.S. ${ }^{*}$ Khvoshchin A.A. Chernomorchenko S.I.
}

\author{
Department of Management and Business, Tyumen State University, Russian Federation \\ *Corresponding author.Email: alks16@gmail.com
}

\begin{abstract}
The complex of social, political and economic challenges generated by the coronavirus pandemic is a reference example of the practical realization of the concept of biopolitics proposed by M. Foucault. The actual type of biopolitical paradigm dictated by the pandemic is understood as the implementation of bio-power by the state thus increasing its presence in all aspects and spheres of society to ensure the biological security of citizens. Modern biopolitics is a combination of forms of social control and state strategies aimed to ensure the survival (biosecurity) and to preserve and develop key social institutions. The key feature of the implemented state biopolitics is the inversion and variability of the strategic discourse. The degree and direction of economic and social damage directly depend on the industry structure of the economy and of the employment structure on small and medium-sized businesses. Biopolitics measures as a set of legal regimes to counter the ongoing COVID-19 coronavirus pandemic, which regulate all spheres of society, should, among other things, provide for their gradual activation when certain disease thresholds are reached. A critical condition for a successful state strategy to counteract the pandemic is the balance of the state's anti-epidemic measures. While proclaiming the main priority of biopolitics to preserve the health of the population and ensure maximum survival of victims, the state also faces the need to protect the processes of economic production and exchange.
\end{abstract}

Keywords: Biopolitics, covid pandemic, state policy, anti-epidemic measures

\section{INTRODUCTION}

The complex of social, political and economic challenges generated by the coronavirus pandemic is a reference example of the practical realization of the concept of biopolitics proposed by M. Foucault. The actual type of biopolitical paradigm dictated by the pandemic is understood as the implementation of bio-power by the state thus increasing its presence in all aspects and spheres of society to ensure the biological security of citizens. Modern biopolitics is a combination of forms of social control and state strategies aimed to ensure the survival (biosecurity) and to preserve and develop key social institutions. The key feature of the implemented state biopolitics is the inversion and variability of the strategic discourse. The degree and direction of economic and social damage directly depend on the industry structure of the economy and of the employment structure on small and medium-sized businesses.

For State governments, biopolitics is becoming a popular paradigm of their activities, since a whole range of factors determines the increase in state presence in the sphere of personal life support, well-being and health of residents of modern countries.

The main reason that the state authorities cannot afford to avoid solving problems of life support and maintaining health is the growing struggle of the modern state for human capital in the context of the globalization of social communications, the expansion of people's interaction with each other and with the natural environment, and a new round of economic development of natural space.

\section{REVIEW}

Today, the new COVID-19 coronavirus infection has manifested itself in 216 countries around the world, confirming its pandemic status that was assigned by World Heath Organization (WHO) on March 11, 2020. According to WHO, as of October 10, 2020, the number of confirmed cases of COVID-19 infection in the world was 36,361,054, the number of deaths reached $1,056,186$. The efforts made by States and international organizations to contain the disease spreading and to minimize its consequences have a certain impact on the situation. Moreover, in a number of countries, the targeted policies and consistent measures are highly effective. A typical example is Vietnam, where the total number of coronavirus tests performed was $1,009,145$, but the number of detected cases was only 1,024, despite the proximity of China from where coronavirus originated. The social consequences and policies of countering the COVID-19 coronavirus pandemic are actively discussed in analytical reviews and works by various authors. The author suggests a paradigm shift in the approach of States to 
developing compensatory measures to maintain and restore the economy and social sphere in comparison with recent economic crisis .

Most countries were not sufficiently prepared for the new threat to human health and life from a new coronavirus infection. Moreover, researchers point out that there is a clear link between the level of health care costs and the death rate from COVID-19: savings on health care costs correspond to higher morbidity and mortality.

In some cases, the authors draw attention to the fact that the world's developing coronavirus epidemic reveals systematic problems of health development, especially clearly demonstrating that socially vulnerable groups of the population (migrants, refugees, asylum seekers, the elderly, etc.) are the first to be hit, for which gaps and problems in the functioning of public health in practice result in lack of guarantees and discrimination in obtaining medical and social assistance, even if it is constitutionally established otherwise. It is noted that the most affected countries are those with a high proportion of the elderly population that did not introduce restrictions in a timely manner due to the COVID-19 pandemic, or whose residents did not comply with these restrictions.

Along with the recognition of the significant risk of the COVID-19 coronavirus pandemic, there are also claims that the scale of the problem, highlighted by WHO, national governments and a number of researchers, is largely exaggerated and does not correspond to the actual situation. Moreover, the "intimidation" of the coronavirus threat is used as a pretext for introducing means of controlling society by the state, restricting people's rights and freedoms, and promoting the commercial interests of medical companies.

\section{KEY FACTORS INFLUENCING THE FORMATION OF PANDEMIC BIOPOLITICS}

State management of the dynamics of the country's population from the point of view of the impact on biological processes in the human population cannot be considered something fundamentally new. The idea that considers the inhabitants of the country as the population specific object of the state management - points to the lifecycle processes that are biological in its basis, and based on Malthusian analysis companies, for over two centuries is one of the key for the formation of public policies. But today, given the growing global connectivity of humanity and the mutual dependencies of regional human communities (and States), it acquires additional properties. 1) People today live in an growing man-made environment, and its impact on population is becoming more diverse. As of $2019,54 \%$ of the world's population lived in urban areas, and its share of the total population is growing from year to year. In Russia, the share of the urban population is even higher than the global average and is $74.6 \%$ of the total population of the country as of January 1, 2020. The human body "collects" from this environment an increasingly significant pathogenic load that weakens the immune system or provokes atypical immune responses, for example, an excessive response of the body to stimulation. 2) Human involvement in the turnover of an increasing number of biomes that exist on Earth, the creation of new ones and, at the same time, the transformation or destruction of the regular ones. This means, in particular, the extraction and distribution of viruses and micro-organisms from enclaves that never contacted with the human population, including pathogens. Most of them are not aimed at a person as a carrier. However, they can change, which is clearly seen in the example of the COVID-19 virus. And in this case, they become a new, frequently significant, threat to human health.

The globalization of human society also means the "globalization" of the evolution of diseases, including the development of not only micro-organisms, pathogens in humans, but also diseases of domestic animals. This also leads to increased risks of adaptation of pathogenic microorganisms that originally live in animal populations to inhabit and reproduce in the human body.

In 1997 - 1998, massive fires that engulfed thousands of square kilometers of rain forests in Sumatra, Sulawesi, Kalimantan, Papua new Guinea and other Islands in Indonesia "smoked" local fruit - eating bats from the forests of Malaysia, forcing them to search for food on mango farms. Pigs on the farm were fed the remains of the mango, which also eat and bats. The Nipah virus, which was originally carried by bats, passed through a simple chain of host carriers: bats, pigs, and humans, causing encephalitis with a $40 \%$ mortality rate among hundreds of ranchers.

Devastating fires have been common in the Amazon since the 2010s. Not the last reason for them is human activity: this is how loggers hide the traces of deforestation, which is becoming more extensive every year, and agribusinesses clear the land for pastures and soybean plantations. People are moving deeper into the Amazon forests, and settlements are growing on their borders. The tanks that local residents use to store water create excellent conditions for breeding mosquitoes that become carriers of diseases: feeding on the blood of both animals (for example, macaques) and people, mosquitoes become natural carriers of chikungunya, dengue fever, yellow fever, zika virus, Hantavirus, leptospirosis and many other infections.

Malaysia and the Amazon are only partial examples of how human activity contributes to the widespread spread of new types of viruses that would otherwise exist locally, within well - defined geographical boundaries. It can be reasonably argued that urbanization, intensive agriculture, industry, mining, hunting, and deforestation are among the most important, if not the most important, factors in the emergence of emergent diseases.

In addition, human activity creates favorable conditions for the reproduction of pathogens that never exist in nature. For example, Chinese "wet" markets: wild animals intended for food are kept crowded, in cramped cages and in unsanitary conditions.

In Russia, ixod mites, carriers of typhoid, encephalitis and borreliosis, have been actively developing in urban parks in recent years. West Nile fever, previously considered as a 
disease of rural residents, now increasingly affects urban residents, not only because the citizens bring the infection from tourist trips to hot countries, but also due to the multiplication of fever vectors - mosquitoes of the genus kuleks in urban ponds, basements of houses and puddles along roads. Outbreaks of this disease occurred in 1999 in Volgograd and Astrakhan regions, in the Krasnodar territory.

These trends are only part of the picture. A more "familiar" and much more dangerous process for medicine and human health is the constant mutation of viruses and microorganisms, which causes, in particular, the ongoing "arms race" between pathogens and developers of antibiotics.

4) Increase in the survival rate of patients, and increase in the number of chronically ill people, and increase in life expectancy exacerbate the issue of maintaining an appropriate level of public health in relation to permanently growing categories of people WHO require constant medical attention. This means an unstoppable increase in the burden on health systems.

5) Risks for humanity are not only diseases with a high life risk, but also epidemics, pandemics with a relatively low mortality rate, causing serious consequences for all spheres of public life. At the same time, the diversity and severity of consequences for human society are growing, mainly because society as a system is becoming more complex. On average, the quality of life has increased significantly (more in developed countries, less in underdeveloped countries), so its relative decline is felt more acutely even in the most prosperous countries.
6) The growing competition between States intensifies rivalry between management practices and basic concepts of public policy, including biopolitics.

Despite the concern about the increasing interference of the state in the life of society, it has become generally accepted that state structures are responsible for a huge layer of public life in the sphere of ensuring the life of people and preserving their health and overcoming the negative consequences of epidemics and pandemics. The state naturally turns out to be "extreme", since it has both significant resources for solving such tasks, and a centralized mobilization apparatus, and an apparatus of coercion.

The dynamics of the formation of protective anti-pandemic mechanisms and population immunity is a key factor in biopolitics and coronacrisis and the basis for making strategic decisions. A critical feature of this pandemic is its long-term nature with a wave course due to the large number of carriers of hidden forms of the disease. This complicates the implementation of quarantine measures and makes the occurrence of recurrent waves of morbidity inevitable.

Modern society is familiar with examples of state biopolitics as a response to the development of an epidemic threat. As an object for comparison, we will take the cholera epidemic in the USSR in 1970, the smallpox epidemic in Yugoslavia in 1972, and the Ebola epidemic in Africa in 2014, and compare it with actual events in the current pandemic

Table 1 Factors and tools of anti-epidemic biopolitics

\begin{tabular}{|c|c|c|c|c|}
\hline $\begin{array}{l}\text { Factor/tool of } \\
\text { biopolitics }\end{array}$ & USSR 1970 Cholera & $\begin{array}{l}\text { Outbreak in } \\
\text { Yugoslavia in } \\
1972 \\
\text { Smallpox }\end{array}$ & $\begin{array}{l}\text { West Africa } 2014 \\
\text { Ebola }\end{array}$ & $\begin{array}{l}\text { Russia } 2020 \\
\text { Coronavirus }\end{array}$ \\
\hline $\begin{array}{l}\text { Channels of } \\
\text { dissemination }\end{array}$ & $\begin{array}{l}\text { Fecal-oral transmission of } \\
\text { Vibrio cholerae }\end{array}$ & $\begin{array}{l}\text { Airborne } \\
\text { transmission } \\
\text { pathways }\end{array}$ & $\begin{array}{l}\text { Fecal-oral, airborne transmission } \\
\text { pathways, in some cases sexual } \\
\text { transmission pathways }\end{array}$ & $\begin{array}{l}\text { Airborne pathway of } \\
\text { infection }\end{array}$ \\
\hline $\begin{array}{l}\text { Territorial } \\
\text { coverage }\end{array}$ & $\begin{array}{l}\text { A significant part of the } \\
\text { territory of the USSR, the } \\
\text { Black sea and Caspian } \\
\text { territorial formations suffered } \\
\text { the most }\end{array}$ & $\begin{array}{l}\text { A significant part } \\
\text { of the territory of } \\
\text { Yugoslavia, } \\
\text { Kosovo and } \\
\text { Metohija are more } \\
\text { affected }\end{array}$ & $\begin{array}{l}\text { Territory Of West Africa - Guinea, } \\
\text { Sierra Leonne, Liberia. }\end{array}$ & $\begin{array}{l}\text { Almost the entire territory of } \\
\text { the Russian Federation. }\end{array}$ \\
\hline $\begin{array}{l}\text { Timeline and } \\
\text { dynamics of the } \\
\text { epidemic. }\end{array}$ & $\begin{array}{l}\text { The first outbreak was } \\
\text { detected in Indonesia in } \\
1961, \text { then the infection } \\
\text { spread to the territory of } \\
\text { Indochina and in } 1965 \text { the } \\
\text { first outbreak was registered } \\
\text { in the Karakalpak ASSR, the } \\
\text { disease reached its maximum } \\
\text { by } 1970 .\end{array}$ & $\begin{array}{l}\text { Imported to } \\
\text { Yugoslavia from } \\
\text { Saudi Arabia in } \\
\text { 1972, by pilgrims } \\
\text { from Kosovo. A } \\
\text { total of } 173 \\
\text { people were } \\
\text { affected during } \\
\text { the epidemic. }\end{array}$ & $\begin{array}{l}\text { December } 2013 \text { - December } 29 \text {, } \\
2015 \text {, the number of registered } \\
\text { cases is } 28640 .\end{array}$ & $\begin{array}{l}\text { The beginning of the } \\
\text { epidemic on January } 31 \text {, } \\
2020 \\
\text { Number of reported cases } \\
1167805\end{array}$ \\
\hline $\begin{array}{l}\text { Features of the } \\
\text { spread of the } \\
\text { disease. }\end{array}$ & $\begin{array}{l}\text { High morbidity, fast } \\
\text { incubation period ( within } \\
24-48 \text { hours), the most active } \\
\text { cases of infection were } \\
\text { observed in resort areas with } \\
\text { a high concentration of } \\
\text { tourists. }\end{array}$ & $\begin{array}{l}\text { It is transmitted } \\
\text { through contact } \\
\text { with an infected } \\
\text { person, contact } \\
\text { with things, } \\
\text { household items, } \\
\text { and bodily fluids. }\end{array}$ & $\begin{array}{l}\text { The reasons for the rapid spread of } \\
\text { the epidemic were poor hygiene and } \\
\text { sanitation, local funeral customs. }\end{array}$ & $\begin{array}{l}\text { Long incubation period, high } \\
\text { degree of virus transmission, } \\
\text { asymptomatic course in the } \\
\text { early stages. }\end{array}$ \\
\hline
\end{tabular}




\begin{tabular}{|c|c|c|c|c|}
\hline Mortality & $\begin{array}{l}\text { If the disease is moderate or } \\
\text { severe, and there is no } \\
\text { medical care, the risk of } \\
\text { death is high. }\end{array}$ & $\begin{array}{l}36 \text { deaths were } \\
\text { registered }\end{array}$ & 11315 people died & 20545 deaths \\
\hline Preventive actions & $\begin{array}{l}\text { Mass promotion of personal } \\
\text { hygiene - washing hands } \\
\text { with soap, boiling water } \\
\text { before use, etc., distribution } \\
\text { of antibiotics to the } \\
\text { population, quarantine } \\
\text { measures in affected cities. }\end{array}$ & $\begin{array}{l}\text { Total vaccination } \\
\text { against smallpox. }\end{array}$ & $\begin{array}{l}\text { Tekmira Pharmaceuticals of Canada } \\
\text { received a } \$ 140 \text { million grant from } \\
\text { the United States to develop a } \\
\text { vaccine called "TKM-Ebola" and } \\
\text { permission from the U.S. food and } \\
\text { drug administration for limited } \\
\text { human trials of the vaccine } \\
\text { On August } 25,2015 \text {, the head of the } \\
\text { Japanese government Secretariat, } \\
\text { Yoshihide Suga, announced that } \\
\text { Tokyo is ready to provide a drug for } \\
\text { the treatment of Ebola, which was } \\
\text { approved by the Japanese } \\
\text { authorities as a flu medicine, but } \\
\text { has not yet been approved by the } \\
\text { world health organization - } \\
\text { favipiravir (T-705). The drug was } \\
\text { developed by Toyama Chemical, a } \\
\text { subsidiary of Fujifilm. Earlier, its } \\
\text { representatives claimed that the } \\
\text { drug reserves will be enough for } \\
\text { more than } 20 \text { thousand infected } \\
\text { people }\end{array}$ & $\begin{array}{l}\text { Mass promotion of social } \\
\text { distance, wearing PPE } \\
\text { (masks, gloves, respirators). }\end{array}$ \\
\hline $\begin{array}{l}\text { Restriction of } \\
\text { freedom of } \\
\text { movement. }\end{array}$ & $\begin{array}{l}\text { Creation of quarantine and } \\
\text { observation zones, restriction } \\
\text { of access to these zones } \\
\text { (prohibition of passage of } \\
\text { tourist cruise ships, } \\
\text { cancellation of vouchers, } \\
\text { railway and air tickets to } \\
\text { infected territories, control of } \\
\text { movement on highways). } \\
\text { Departure from blocked } \\
\text { localities only after a } \\
\text { bacteriological examination } \\
\text { and a five-day observation } \\
\text { (isolation with observation). } \\
\text { Official quarantine was } \\
\text { introduced only in the centers } \\
\text { of infection themselves, } \\
\text { namely in Kerch, Odessa and } \\
\text { Astrakhan. All other resort } \\
\text { cities of the Crimea, the coast } \\
\text { of the Azov and Black seas } \\
\text { tried to get rid of visitors as } \\
\text { much as possible. }\end{array}$ & $\begin{array}{l}\text { Complete closure } \\
\text { of borders, } \\
\text { prohibition of } \\
\text { movement } \\
\text { between cities, } \\
\text { prohibition of } \\
\text { staying away from } \\
\text { home. }\end{array}$ & $\begin{array}{l}\text { The termination of air } \\
\text { communication with the States with } \\
\text { reported outbreaks of the disease, } \\
\text { the cancellation of mass events. } \\
\text { Introduction of quarantine in Sierra } \\
\text { Leone. }\end{array}$ & $\begin{array}{l}\text { Restrictions on flights, } \\
\text { railway messages, and city } \\
\text { travel. }\end{array}$ \\
\hline $\begin{array}{l}\text { Other forms of } \\
\text { social control }\end{array}$ & $\begin{array}{l}\text { The appearance of so-called } \\
\text { sanitary patrols, social } \\
\text { censure of vacationing } \\
\text { "savages", food merchants on } \\
\text { the beaches of Soviet resorts. }\end{array}$ & & & $\begin{array}{l}\text { Promotion of quarantine and } \\
\text { isolation measures in the } \\
\text { state media. Attempts to } \\
\text { introduce travel passes in } \\
\text { cities. }\end{array}$ \\
\hline Medical action. & $\begin{array}{l}\text { Mass preventive therapy with } \\
\text { antibiotics. }\end{array}$ & Total vaccination. & $\begin{array}{l}\text { The fight against the epidemic is } \\
\text { complicated by the fact that at the } \\
\text { moment there is no specific } \\
\text { treatment or vaccine for either } \\
\text { humans or animals. Several } \\
\text { vaccines are being tested, but there } \\
\text { are no vaccines ready for clinical } \\
\text { use. Seriously ill patients need } \\
\text { intensive symptomatic therapy. In } \\
\text { severe cases, intensive maintenance } \\
\text { therapy is required. Patients often } \\
\text { suffer from dehydration and need } \\
\text { intravenous infusions or oral } \\
\text { rehydration with solutions } \\
\text { containing electrolytes. }\end{array}$ & $\begin{array}{l}\text { At the moment, therapeutic } \\
\text { measures are limited to } \\
\text { symptomatic and preventive } \\
\text { therapy, and there is a } \\
\text { widespread need for the use } \\
\text { of ventilators due to lung } \\
\text { damage. The Sputnik-V } \\
\text { experimental vaccine has } \\
\text { been developed. Limited } \\
\text { vaccination of the population } \\
\text { with this vaccine is carried } \\
\text { out. }\end{array}$ \\
\hline
\end{tabular}




\begin{tabular}{|c|c|c|c|c|}
\hline $\begin{array}{l}\text { The extension of } \\
\text { the health system. }\end{array}$ & $\begin{array}{l}\text { Deployment of quarantine } \\
\text { centers and hospitals in } \\
\text { school buildings. }\end{array}$ & $\begin{array}{l}\text { Establishment of } \\
\text { quarantine and } \\
\text { vaccination } \\
\text { centers. }\end{array}$ & $\begin{array}{l}\text { WHO and other partners are } \\
\text { mobilizing and deploying additional } \\
\text { specialists to provide assistance. } \\
\text { The necessary material and } \\
\text { logistical resources are also being } \\
\text { mobilized for supporting patient } \\
\text { management and for all aspects of } \\
\text { outbreak management. }\end{array}$ & $\begin{array}{l}\text { Conversion of medical } \\
\text { centers to infectious diseases } \\
\text { hospitals, as well as } \\
\text { redirecting a number of } \\
\text { doctors to fight coronavirus } \\
\text { infection. }\end{array}$ \\
\hline $\begin{array}{l}\text { International } \\
\text { cooperation. }\end{array}$ & No. & $\begin{array}{l}\text { The WHO Donald } \\
\text { Henderson } \\
\text { mission to } \\
\text { Yugoslavia. }\end{array}$ & $\begin{array}{l}\text { Doctors without borders, and a } \\
\text { number of other Organizations are } \\
\text { sending specialists to infected areas. }\end{array}$ & $\begin{array}{l}\text { In the early stages - volunteer } \\
\text { movement of doctors in } \\
\text { China, Europe and the USA. } \\
\text { Supplies of protective } \\
\text { equipment and medical } \\
\text { equipment. }\end{array}$ \\
\hline $\begin{array}{l}\text { Affected sectors } \\
\text { of the economy. }\end{array}$ & $\begin{array}{l}\text { Primary direct damage: } \\
\text { tourism, agriculture (crop } \\
\text { destruction in the region due } \\
\text { to fears of spreading } \\
\text { cholera), trade. }\end{array}$ & & & $\begin{array}{l}\text { In one way or another, } \\
\text { almost all sectors of the } \\
\text { Russian economy were } \\
\text { affected - air and railway } \\
\text { transportation, retail and } \\
\text { WHOlesale trade, in view of } \\
\text { the quarantine closure - } \\
\text { enterprises of various } \\
\text { industries, the educational } \\
\text { process, the sphere of } \\
\text { medicine, and much more. }\end{array}$ \\
\hline $\begin{array}{l}\text { Compensation of } \\
\text { losses for the } \\
\text { population. }\end{array}$ & $\begin{array}{l}\text { The Council of Ministers of } \\
\text { the USSR ordered to extend } \\
\text { business trips and vacations } \\
\text { with the preservation of } \\
\text { wages for all those WHO are } \\
\text { forced to stay in the } \\
\text { quarantine zone. }\end{array}$ & & & $\begin{array}{l}\text { Benefits for families with } \\
\text { children under 16, an } \\
\text { increase in unemployment } \\
\text { benefits, benefits and support } \\
\text { for volunteers, a moratorium } \\
\text { on the payment of penalties } \\
\text { for housing and utilities } \\
\text { services, credit holidays. }\end{array}$ \\
\hline $\begin{array}{l}\text { Compensation for } \\
\text { the economy. }\end{array}$ & & & & $\begin{array}{l}\text { Tax deferral for small and } \\
\text { medium-sized businesses, } \\
\text { support for micro-enterprises, } \\
\text { tax deferral, a moratorium on } \\
\text { bankruptcy, direct financial } \\
\text { support for a number of } \\
\text { industries at no cost, a } \\
\text { moratorium on business } \\
\text { verification. }\end{array}$ \\
\hline
\end{tabular}

\section{STRATEGIC BIOPOLITICS MEASURES TO COUNTERACT THE DEVELOPMENT OF THE PANDEMIC}

An actual strategic approach to the development of state biopolitics has become a necessity today. Research measures, administrative and organizational measures, systematic investments in the creation of a network of institutions to counter the pandemic threat and in the formation of strategic stocks of medicines should become an integral part of this approach.

The measures taken should be proactive and promote, among other things, the formation of a mobilization mechanism.

1. It is necessary to construct a nationwide network of medical and social institutions that can be transformed into infectious diseases hospitals and quarantine centers. The main task, is to stop resource optimization in medicine and, in general, social services, promptly determine the need for such institutions to develop a territorial layout of these centers, their equipment and planned to fill the links in the network. At the same time, excessive centralization should be avoided, giving priority to decentralized forms of placement.

2. It is important to create strategic stocks of medical equipment and protective equipment, both within the framework of equipping medical centers and using geographically distributed storage facilities.

3. It is vital to develop our own national industry for the production of medical equipment and protective equipment, which can be mobilized in a short time for the accelerated and large-scale production of necessary medical products. At the same time, it is necessary to provide for increasing the export potential of such an industry.

4. Formation of a specific policy to promote the development of the pharmaceutical industry:

4.1. Maintain and develop a full cycle of national production of vital and essential medicines for medical use. Moreover, it is important to stimulate the rapid development of the medical products industry by providing the most favorable treatment to pharmaceutical research centers of 
domestic pharmaceutical corporations and promoting the introduction of AI technologies;

4.2 Develop a system for timely review and adaptation of the state order with changes made to the list of vital and essential medicines for medical use, taking into account the received anti-epidemic practice. It is important to establish a mechanism for rapid assessment and approval of proposed changes to the lists;

4.3. Introduce mass production of universal anti-epidemic first aid kits (analogous to the cold war AI-2 first aid kit), which will dramatically reduce the burden on the health system by implementing self-treatment protocols in patients with mild to moderate forms of the disease. This measure should be supported by an appropriate awareness-raising campaign.

5. Creation and/or financing of research centers and research in the field of epidemiology, Virology. The collection of the Russian Institute of Virology currently contains 2,800 strains and more than 600 species belonging to 18 families. At the same time, according to one estimate, there are at least 320 thousand species of mammalian viruses. "Preventive" research activities aimed at identifying potential epidemiological threats and anticipating the development of measures to counter them are important.

6. Further development of "contactless" communication technologies in society that do not require personal "physical" contacts of people. Actual information technologies already provide significant opportunities for

\section{REFERENCES}

[1] M. Foucault, The birth of biopolitics: lectures at the College de France, 1978-1979, Basingstoke: Palgrave Macmillan, 2008.

[2] Sherpa D. Estimating Impact of Austerity policies in COVID-19 fatality rates: Examining the dynamics of economic policy and Case Fatality Rates (CFR) of COVID-19 in OECD countries, medRxiv preprint, 2020. https://doi.org/10.1101/2020.04.03.20047530

[3] Nangtyngshain H., COVID -19 and Its Impacts on Tourism in Meghalaya, India, JETIR 7(9) (2020) 10351041

[4] A. Johnson COVID-19 - Evidence of Fraud, Medical Malpractice, Acts of Domestic Terrorism and Breaches of Human Rights, 2020.

[5] H. M. Lell, Instituciones socio-jurídicas en tiempos de pandemia por coronavirus: cuando lo biológico resignifica lo cultural, Opinión Jurídica 19(40) (2020) 109-124. https://doi.org/10.22395/ojum.v19n40a5

[6] J. S. Madray, The Impact of Covid-19 on Event Management Industry, Int. J. of Engineering Applied remote communication and the implementation of many significant actions, that involves interaction between people. The existence and spread of the Internet, the emergence of new standards for wired and wireless communication helps to achieve more or less the effect of presence, reliably identify participants in communication and guarantee the authenticity of communication. The development of $\mathrm{AR}, \mathrm{VR}$, and robotics technologies gives reason to hope that in the future even those interactions that require direct physical contact (haircuts, medical manipulations, etc.) can be performed remotely without loss of quality.

\section{CONCLUSION}

Biopolitics measures as a set of legal regimes to counter the ongoing COVID-19 coronavirus pandemic, which regulate all spheres of society, should, among other things, provide for their gradual activation when certain disease thresholds are reached. A critical condition for a successful state strategy to counteract the pandemic is the balance of the state's anti-epidemic measures. While proclaiming the main priority of biopolitics to preserve the health of the population and ensure maximum survival of victims, the state also faces the need to protect the processes of economic production and exchange.

Sciences and Technology, 2020.

doi:10.1108/17582951211229690.

[7] M. R. Silveira, N. F. F. Junior, R. Giraldi Cocco, R. M. Felácio, L. A. Rodrigues, Novel coronavirus (sarscov-2): spatial diffusion and another level for the socialization of investments in Brazil, Revista brasileira de estudos urbanos e regionais 22 (2020) e202024en. https://doi.org/10.22296/2317-1529.rbeur.202024en;

[8] G. Moschonas, Paradigm Shifts in the Light of the Past: the 1929 Crash, the Great Recession of 2008 and the COVID-19 Crisis, OpenDemocracy, 2020.

[9] L.M. Sartoretto, Situação De Refugiados e Migrantes No Contexto Da Pandemia De Covid-19. Revista Perspectiva, 2020.

[10] R.V. Santos, C. E. A. Coimbra Jr, A.L. Pontes, Um "fato social total": COVID-19 e povos indígenas no Brasil, Cad. Saúde Pública 36(10) (2020) e00268220/

[11] S. Sazib, National Preparedness Plan for COVID19: Strategic Policy Option for Bangladesh Policy Paper. Bangladesh University of Professionals, 2020.

[12] H.B. Schäfer, Financing the corona crisis in the European Union, meandering between national selfishness and community thinking. Sergio García- 
Long (ed.), Derecho de los desastres: Covid-19, Lima: Pontificia Universidad Católica del Perú 2 (Estudios internacionales), 2020, pp. 1239-1243.

[13] S.J. Anthony, J.H. Epstein, K.A. Murray, I. Navarrete-Macias, C.M. Zambrana-Torrelio, A. Solovyov, R. Ojeda-Flores, N.C. Arrigo, A. Islam, S. Ali Khan, P. Hosseini, T.L. Bogich, K.J. Olival, M.D. Sanchez-Leon, W.B. Karesh, T. Goldstein, S.P. Luby, S.S. Morse, J.A.K. Mazet, P. Daszak, W.I. Lipkin, A strategy to estimate unknown viral diversity in mammals, mBio 4(5) (2013) e00598-13. doi:10.1128/mBio.00598-13.

[14] A. Somma, La Unión Europea en tiempos de coronavirus, Sergio García-Long (ed.), Derecho de los desastres: Covid-19, Lima: Pontificia Universidad Católica del Perú 2 Estudios internacionales, 2020, pp. 1239-1243.

[15] T. Werron, L. Ringel, Pandemic Practices, Part One. How to Turn "Living Through the COVID-19 Pandemic" into a Heuristic Tool for Sociological Theorizing. Sociologica 14(2) (2020) 55-72. https://doi.org/10.6092/issn.1971-8853/11172

[16] WHO (World Health Organization) Coronavirus Disease (COVID-19) Dashboard. 2020.

https://covid19.WHO.int/
[17] Worldometer. COVID-19 Coronavirus Pandemic Dashboard. 2020.

[18] S.I. Dolgov, Yu.A. Savinov, Impact of the outbreak of the new coronavirus on international trade, Russian Foreign Economic Bulletin 2 (2020) 7 - 18.

[19] A.I. Kologorov, O. V. Kedrova, D. A. Pakhomov, N.V. Piskunov, A.I. Kovtunov, A.S. Vasenin, V.V. Kabin, A.A. Ilyukhin, I. V. Gracheva, A.S. Razdorsky, V.A. Safronov, Patterns of cholera spread in the Volga basin in 1970-1973, Problems of Particularly Dangerous Infections 104 (2010) 22 - 28.

[20] S.A. Morozov, How Hard Will The Outbreak of Coronavirus Damage the Global Economy? Scientific electronic journal "Meridian" 8 (42) (2020) 456-458

[21] Experience of States in Combating the COVID-19 Pandemic. Digest of the Accounts Chamber of the Russian Federation. Accounts Chamber of the Russian Federation, 2020, 271 p. Official website of the Accounts Chamber of the Russian Federation. https://mbio.asm.org/content/4/5/e00598-13

[22] V.F. Popov, Epidemic of cholera in the USSR in 1970, BIOpreparations. Prevention, Diagnosis, Treatment (2011) 36 - 38 . 